\title{
National Higher Courts and the ratification of EU treaties
}

\section{Introduction*}

Landmark decisions by Higher Courts $^{1}$ on the Maastricht and Lisbon Treaties have attracted attention to the substantive arguments upholding the final decisions, with regard to their constitutionality. Authors underline the warnings contained in some of these judgements, which impose a number of constraints for future EU reforms. Paradoxically, the specific decision (i.e. whether the Constitution has to be amended in order to ratify a given treaty) has surprisingly attracted less attention. And yet these decisions are the key to fully understanding the position of Higher Courts vis-à-vis European Union law and European integration in general. Decisions against the constitutionality of a given treaty generally require a constitutional revision. Implementing this decision may, however, be difficult if the institutional requirements for constitutional revision are very high. Hence, Higher Courts may also take into account the effects of their decision and its eventual implementation. I argue that Higher Courts have generally opted not to declare treaties as being against the Constitution in an institutional context which has very rigid procedures for constitutional revision. This happens regardless of the substantive contents of the arguments given.

The dominant focus on "reasoning" and "arguments" rather than on specific decisions correlates strongly with the considerable preponderance of legal scholars in the study of the behaviour of the courts in Europe. This approach affects explanatory

\footnotetext{
* An earlier version of this paper was presented at the RECON Workshop "With or without Lisbon: Continuous institutional change in the EU", Amsterdam 15-16 May 2009 and at the IPSA World Congress in Santiago de Chile, July 2010. I am very grateful to the comments and criticism received there. Juan A. Mayoral also provided valuable criticism on the main thesis of the paper while Pablo J. Castillo discussed earlier drafts. The Spanish Micinn Project CSO2009-06971 "Instituciones nacionales e integración Europea: la ratificación de los tratados de reforma de la UE" and the VI FP RECON Project Contract No. FP6-028698 have provided funding for this research.

${ }^{1}$ Higher Courts include both constitutional courts and supreme courts in these jurisdictions which do not have specialized systems for the control of constitutionality.
} 
capacity: looking at the merits or arguments explains the outcome as a logical construction, to which any other alternative possible logical construction may be opposed. Within this approach, the outcome is not explained through variables which are exogenous to the reasoning itself (such as preferences, institutions, etc.). For instance, a key European legal scholar, Miguel Maduro, argued that if a national court is aware that a decision to be taken will become part of European law- as interpreted by the 'community' of national courts- in future cases it will internalize the overall consequences of its decisions (Maduro; 2000: 124). The outcome is explained by something like the "good will" or "knowledge" of the judges. Legal theorists seem to trust in a kind of 'heroic' court which, drawing on inspiration from different sources, is able to employ a rational and reflexive process in order to produce a balanced outcome.

Alternative explanations from European political science are scarce, partly because of the limited interest in judicial politics (some exceptions are Golub; 1996; Stone Sweet; 2000; Brouard; 2009 and Hönnige; 2009); this has triggered calls for increased research on the interaction between Courts, governments and parliaments (Hönnige; 2011). Alec Stone Sweet (2000) has developed a comprehensive "theory of constitutional politics" which proposes two self-reinforcing mechanisms: politicization and judicialization. "Politicization" refers to the activation of constitutional review in order to alter legislative outcomes, while "judicialization" refers to the production of normative discourse by judges, and the reception of the rules emanating from normative discourse by legislators. The theory is slightly imbalanced when dealing with the causal mechanism explaining institutional outcomes: minority legislators find the politicization strategy extremely useful for reversing majority legislation. But what explains the outcomes of the Courts? Stone Sweet proposes two tactics (which are not necessarily explanatory): judges defend their behaviour normatively, treating constitutional 
provisions as providing in themselves all the necessary materials for the resolution of the dispute, isolated from political and policy disputes. Secondly, Courts anticipate political reactions to their decisions, trying to limit negative reactions.

This second tactic comes closest to providing an explicit and robust thesis to explain the behaviour of the Courts beyond the logic of the law itself, and interpreting the Courts as strategic actors. More directly, other authors (Clinton; 1994) (Carrubba; 2000; 2009) have presented Courts as strategic actors whose basic aim is to reinforce their own role and authority within a given legal setting. In the EU context, this implies that judges and Courts will seek to extract advantage (in terms of their own authority) from the integration process (Garrett et al; 1998). More nuanced approaches argue that court decisions depend not only on anticipating choices which may be made by other actors, but also on the strategic goals that the Courts may pursue, and the institutional setting in which the Courts' own choices are made (Epstein and Knight; 2000). This is precisely the approach that this paper takes. The next section sets the theoretical background of the so-called implementation problem, which refers to the calculation that Courts have to make concerning the likelihood of a sentence being implemented. The following two sections summarise the institutional features of Higher Courts (3) and the institutional requirements for constitutional reform (4), which may provide explanatory variables linked to the institutional setting of Courts. Section 5 presents the decisions of the Courts and their strategies (either argumentative or procedural); section 6 relates them to institutional features; and section 7 explains decisions in relation to the institutional obstacles to their implementation. I argue that Courts tend to avoid a sentence of unconstitutionality when the requirements for constitutional amendment are very high (i.e. the intervention of veto players). The conclusions summarize the argument and suggest further lines of research. 


\section{Institutional determinants of decisions of Higher Courts: the}

\section{implementation problem}

This paper argues that the institutional environment constrains and affects Court decisions (Vanberg; 2001:346). The institutional context is particularly important given the so-called "implementation problem" (Rosenberg; 1991); i.e. the fact that Court rulings need to be transferred into legislation. Hence, implementation requires the active participation of actors other than the Court itself. The implementation problem proves particularly acute when courts adjudicate on the constitutionality of an EU reform Treaty: in the case of a negative verdict, Courts are aware of the institutional background conditioning implementation. Courts know that EU treaties, once signed, have to be accepted in toto and they do not allow partial derogations introduced during the ratification process (de Witte; 2004). This means that procedures for resolving an eventual declaration of unconstitutionality involve either constitutional reform or renegotiation of the treaty in order to modify the contested provisions. But since renegotiation depends on acceptance by other governments/states, meaning that all other states will bow to the Court ruling, implementation depends basically on domestic constitutional reform. Courts know the domestic requirements for constitutional revision, and they may also be aware of the preferences of political actors with regard to both ratification and constitutional reform. Normally, rules for constitutional amendment almost always prescribe requirements which are more stringent than a legislative majority; they may, for example, also involve veto players, i.e. referendums and/or intervening elections. Additionally, courts also know how "externalities" may effect an eventual declaration of unconstitutionality: given the requirement for unanimity, an eventual negative decision may halt or even cancel ratification for the 
whole of the EU. Thus, while prima facie cases concerning the constitutionality of EU reform treaties provide a golden opportunity for Courts to deliver powerful decisions that assert the supremacy of national constitutions and enforce profound constitutional amendments, the rules for constitutional reform clearly establish the implementation costs conditioning the Courts' decisions and, in this way, may eventually limit their ambition. Hence, ratification presents a moment at which the institutional constraints for the implementation of court decisions are fully visible, and a good moment to test whether they may affect the Courts' decisions.

This paper examines all Higher Court decisions on the constitutionality of EU reform treaties (all the so-called "grand bargains" from the SEA to Lisbon) during the ratification process. The Treaties considered include those from the ECSC Treaty (1951) to the Treaty of Lisbon. Together with the usual cases (i.e. SEA, Maastricht, Amsterdam, Nice and the EU Constitution), the EDC Treaty is also considered, since it triggered two challenges before the German Constitutional Court. Four treaties, the ECSC Treaty, the EEC/EAEC Treaties, and the Treaty of Nice did not call for any demand for rulings from the Courts. Altogether, Higher Courts have ruled in 36 cases assessing the compatibility of new reforms with the domestic constitutional order (see Table 2 below). Taking into account the ever growing number of Member States, and the continuous pace of treaty reforms, the figure is not large. The increase in the number of constitutional jurisdictions brought about in successive enlargements may give an immediate explanation for the growth of cases and, tellingly, the Lisbon Treaty concentrates $42.5 \%$ of these (i.e. 17$)$.

Accession Treaties, on the other hand, have been also challenged before Higher Courts in 4 cases: Poland, Latvia, Estonia and the Czech Republic. These treaties pose a similar implementation problem, although there are some significant differences: 
namely, if a $\mathrm{CC} / \mathrm{HC}$ forces a constitutional revision on accession, the would-be member state assumes the full cost of not implementing the decision, and there is no externalization effect. Thus, these four cases can be added to the sum total of cases to bring the count to 40 . On the other hand, rulings concerning domestic acts in relation to EU law also raise interesting issues: the German Constitutional Court sentence against Eurobonds, the Polish Constitutional Court limitation of "direct effect", or the Czech Constitutional Court limitation on the use of fundamental rights all illustrate compelling cases of sentences against EU law. They, however, present a very different implementation problem to that of the declaration of unconstitutionality of a Treaty and, hence, they are not integrated into our research. No doubt a fruitful avenue in the future may be to compare sentences with different implementation problems.

\section{Institutional design of official bodies responsible for the constitutionality of treaties}

Higher Courts are a constant feature in all Member States, although their design varies widely. Three criteria determine the institutional configuration of the Courts controlling the constitutionality of EU reform treaties. The first is the nature of the jurisdiction (i.e. ordinary or specialized), the second is the moment of control (i.e. ex ante or ex post ratification) and the third refers to the legitimated subject (i.e. the subject that may trigger constitutional revision). Table 1 below summarizes the classification of Member States according to these three criteria.

Table 1

Type of jurisdictions, moment of control and legitimated subject

\begin{tabular}{|l|l|l|l|}
\hline & Constitutional & Ordinary & Ad hoc \\
\hline
\end{tabular}




\begin{tabular}{|c|c|c|c|}
\hline & jurisdiction & jurisdiction & jurisdiction \\
\hline $\begin{array}{l}\text { Preliminary control } \\
\text { on constitutionality } \\
\text { of treaties }\end{array}$ & $\begin{array}{l}\text { Belgium (C, P, G, O) } \\
\text { Bulgaria (P, G, H, O) } \\
\text { Czech Republic (P, G, H, C, O) } \\
\text { France (H, G, P) } \\
\text { Germany (G, P, C, O) } \\
\text { Hungary (H, G, C) } \\
\text { Latvia (H, P, G, O, C) } \\
\text { Lithuania (H) } \\
\text { Poland (H) } \\
\text { Portugal (H) } \\
\text { Romania (L) } \\
\text { Slovakia (H, G, C) } \\
\text { Slovenia (C, H, G, P) } \\
\text { Spain (G, P) }\end{array}$ & $\begin{array}{l}\text { Ireland (H, C) } \\
\text { UK (C) } \\
\text { Estonia (G [legal } \\
\text { chancellor]) }\end{array}$ & $\begin{array}{l}\text { Finland } \\
\text { Sweden }\end{array}$ \\
\hline $\begin{array}{l}\text { No preliminary } \\
\text { control on } \\
\text { constitutionality of } \\
\text { treaties }\end{array}$ & $\begin{array}{l}\text { Italy } \\
\text { Austria } \\
\text { Malta }\end{array}$ & $\begin{array}{l}\text { Greece } \\
\text { Denmark } \\
\text { Cyprus } \\
\text { Luxembourg } \\
\text { The Netherlands }\end{array}$ & \\
\hline
\end{tabular}

Source: Own elaboration

Legend. C: Citizens. P: Parliament; G: Government. H: Head of State (i.e. President). O: Other

3.1 The nature of the jurisdiction

Constitutional doctrine traditionally distinguishes between specialized constitutional jurisdiction, in which a constitutional court has the monopoly of adjudicating on the constitutionality of laws, and non-specialized or disperse jurisdiction, in which ordinary courts (mainly Supreme Courts) have the power to adjudicate on the constitutionality of laws. Within the EU, both models exist, but specialized constitutional jurisdictions dominate overwhelmingly (17 to 10 , see Table 1 above). In 1951, at the signing of the ECSC Treaty, only Germany and Italy had constitutional courts. France (1958) and Belgium (1980) later created this kind of jurisdiction, while over the next four decades Mediterranean, Nordic and Central European enlargements have tilted the balance towards this model.

Ordinary jurisdictions without a constitutional court are less common among EU Member States (10 cases). In the case of the Netherlands, the Constitution excludes control of the constitutionality of treaties. Two of the states without a Constitutional Court, Finland and Sweden, nevertheless have specific sui generis mechanisms for 
controlling EU treaties. In both countries, a Committee of the Parliament itself reviews the constitutionality of treaties. Even though membership is restricted to MPs, the committee actively seeks the advice and involvement of constitutional law experts and, backed by such a large body of expertise, their opinions are regarded as highly consensual and indisputable. Opinions of advisory bodies (such as the Dutch Council of State) are not considered, since they are not jurisdictional bodies and their opinions do not bind national authorities; i.e. they do not pose a real implementation problem.

\subsection{Ex ante and ex post modalities of control}

The second institutional feature is the moment at which control is exercised: most member states (19) have the option of examining the constitutional compatibility of Treaties before their approval by the national parliament (preliminary or ex ante control). The remaining member states have foregone this option, and in Luxembourg and the Netherlands control of the constitutionality of treaties is excluded. While ex ante control is associated mainly with constitutional courts, ordinary jurisdictions more usually act with ex post control, although preliminary control exists in several states. A different, although related, issue refers to the object of control: in forms of direct control, courts directly examine the constitutionality of a Treaty, while in indirect control, only the revision of the ratifying law is permitted. In practice, this second option has no real significance since courts have normally taken advantage of the revision of the ratifying law in order to extend the process to the treaty itself.

\subsection{Legitimated subjects}


The third institutional characteristic is the legitimated subject which activates a claim before the Court: when there is a preliminary ruling acting as a mechanism of constitutional control the intervention of the courts is not automatic. On the contrary, other (political) actors need to activate participation by the Court. The typology of legitimate actors is quite diverse, and it normally involves other state organs, all of which have different requirements, be they the Head of State, government or parliament. The capital letters in Table 1 refer to the potential legitimate subjects or "triggers" of court challenges in each Member State, while the "Claimant" column in Table 2 identifies the actual claimant in each specific case.

Although this paper does not focus on their motives, it is worth noticing that political actors have increasingly found that the courts may be used to serve different strategic goals: to impede or halt ratification; to trigger a restrictive interpretation on the treaty or to promote institutional changes, etc. The following paragraphs describe the presence of different subjects in different processes: while the executive tends to use appeals to secure its pro-ratification stance, legislatures and, particularly, citizens tend to use appeals to impede ratification. The position of Presidents in this regard is less clear-cut, and there are examples of actions taken in both directions.

\subsubsection{Legislatures as triggers: constitutional appeal as an instrument of opposition}

In eight Member States, Parliaments may request a review of the constitutionality of the Treaties, although the requirements to start Court proceedings may be very demanding and render it very difficult to challenge a majority decision. For instance, the 1992 French constitutional reform introduced parliamentary appeals for constitutional review and immediately two different groups of MPs challenged the 
Maastricht Treaty. Altogether, Parliaments have acted as challengers in 11 occasions in the Czech Republic, Finland, France, Germany and Poland. The inclusion of the Finnish case, although technically correct, must be treated carefully: the same body requests a review and performs it. Thus, while in other cases a challenge coming from the parliament against the will of the majority may express an underlying conflict, this is not necessarily so in the Finnish case.

\section{3.2. Executives as triggers: rulings as safety nets}

Governments can demand a preliminary ruling on the constitutionality of a treaty in ten EU Member States. Since governments negotiate and sign the treaty, it may be assumed that by involving constitutional courts they wish to maximize the chances of positive ratification. Evidence confirms that only in a few cases have governments activated a court case on an EU reform Treaty. Strictly speaking, only the Spanish and French governments have requested the intervention of the Constitutional Court. In France, this occurred in conjunction with the President's appeal in 1992. In Spain, the government has twice requested a ruling from the constitutional court; once in relation to the Maastricht Treaty, and again in relation to the EU Constitution.

\subsubsection{Presidential prerogative to launch Court appeals as a counter power}

Government containment strategy may be altered when the President retains the prerogative of demanding a preliminary ruling on the constitutionality of the treaties and decides to use it. This option exists in 9 member states. In three of these, i.e. Germany, Poland and Portugal, the President may act on the parliamentary ratification 
law, while in the Czech Republic and Poland Presidents may request a preliminary ruling on the treaty itself prior to its signature. This is functionally equivalent to the former cases.

Presidents have used this prerogative in three countries (Germany, France and the Czech Republic). French Presidents have requested preliminary rulings on all EU reform Treaties since Maastricht. In none of these cases have French Presidents contradicted the government's position; they sought rather to smooth ratification of the treaty through the identification of the specific elements for constitutional reform following these treaties. The cases of the German and Czech Presidents illustrate appeals which are not totally in line with the position of governments. In 1952, the German Federal President requested an advisory opinion from the Court on the constitutionality of the EDC Treaties as result of a "compromise" that the President had arranged with the opposition leader from the SPD. However, the President withdrew his request in December that year (Loewenstein; 1955).

The Czech President used his prerogative against the Lisbon Treaty which he had harshly criticized. Before ratification, President Klaus sent a letter to the President of the Constitutional Court requesting his personal opinion on the EU Constitution. Reasonably, the court considered the question "premature". Once the Court had pronounced itself on a previous Senate appeal and once parliament had completed ratification, President Klaus challenged the Treaty a second time before the $\mathrm{CC}$. The Court rejected his claims and reaffirmed its former verdict.

\subsubsection{Citizens as triggers of appeals}


Citizen (i.e. non institutional agent) appeals are the main source of action against EU Treaties in ratification processes, and account for 21 occurrences (see Table 2). Of course, political actors such as MPs may also use this procedure for themselves and, in fact, this has happened on several occasions. Citizen intervention is naturally and logically associated with the existence of ordinary jurisdictions and with ex post forms of control. However, citizens in Ireland (SEA), Denmark (Maastricht) and the UK (Treaty of Lisbon) have requested ex ante court action. In Ireland, after completing the parliamentary procedure for ratification, an individual named Raymond Crotty brought a case before a High Court and secured an injunction that prevented the government from lodging the instrument of ratification. In Denmark, citizens twice challenged the constitutionality of the Maastricht Treaty, and in the UK citizens also launched two challenges against the ratification of the Lisbon Treaty (the first was Conservative MP Bill Cash; the second business tycoon Stuart Wheeler).

A priori, constitutional jurisdictions are designed as a mechanism for interinstitutional arbitration; hence citizens do not have a strong position as claimants. Nevertheless, several member states (inter alia, Belgium, Czech Republic, Germany, Hungary, Latvia and Slovakia) have jurisdictions open to citizens for launching constitutional challenges, and citizens have used this opportunity widely. The first case happened in 1993 in Germany when the Euro-sceptic Manfred Brunner challenged the constitutionality of the Maastricht Treaty. German citizens also activated appeals against the EU Constitution (2005) and the Lisbon Treaty (2008 and 2009). Similarly, citizens have also initiated challenges in Latvia, Slovenia and Slovakia, demanding a referendum on the EU Constitution; in Hungary an individual citizen challenged the Act of Ratification of the Lisbon Treaty; in Austria citizens launched appeals, once on the 
EU constitution and twice on the Lisbon Treaty; and in Belgium citizens appealed once on TEU and three times on the Lisbon Treaty.

\section{Institutional environment: requirements for constitutional amendment}

Together with the specific institutional characteristics of the jurisdiction of Higher Courts, the procedures for constitutional revision play a role as explanatory variables. As mentioned above, implementation of a negative ruling can only be securely achieved through a constitutional reform. Normally, procedures of constitutional reform need to meet requirements which demand more than a mere parliamentary majority. Courts are well versed in these requirements and, in the event of a ruling of non-constitutionality, they know that these may include a parliamentary majority (as is the case with ordinary legislation) as well as the concurrence of the opposition and/or other actors. Table 4 below summarizes such requirements.

As for parliamentary majorities, all Member States (with the exception of the UK because of its constitutional specificity) require a higher threshold than a simple majority. A significant number of states (Austria, Germany, Hungary, Finland, Latvia, Poland and Slovenia) require a two-thirds majority. They may also add further procedural requirements, such as delays between successive votes in the same legislature. Spain and the Czech Republic require majorities of three fifths and France, the only case requiring a simple majority, requires the approval either of the Congress (a joint meeting of both chambers) or a referendum.

A second group of states demands the inclusion of veto players; i.e. a new actor intervening in the process, different from the usual state institutions which intervene in 
ordinary legislation, such as parliaments, executives and heads of state. In constitutional reform regions or states may be such additional veto players, but no European constitution recognizes a veto power for regions or states. Voters, on the other hand, intervene in constitutional reforms by means of two different procedures; they can either ratify the parliamentary vote in favour of constitutional amendment in a referendum, or else an intervening election can be called between two successive votes by two different legislatures on the same amendment. Referendums are used in Latvia, Slovakia and France whenever constitutional reform affects very important issues, and in Ireland when the ordinary procedure is followed. Intervening elections are used in Belgium, while Denmark and Spain have the most rigid of procedures combining both election and referendum. The inclusion of veto players is crucial for the amenability of a constitution. Thus, Ras and Congleton (2006) conclude that the number of veto players have systematic effects on the amendment rates of (OECD) countries: amendment rates fall when requirements include intervening elections and/or referenda.

Several Member States (such as France, Latvia, Spain or Slovakia) have more than one amendment procedure, depending on the part of the Constitution affected. In this paper, each court case is associated with the eventual or actual procedure used or invoked in the specific case (see Table 3). In France, the use of a referendum instead of the Congress is a discretionary decision for the President. On all occasions, Presidents have selected to convoke Congress, irrespective of the parallel calling of a referendum for the ratification of the Treaty, as happened in 1992 (Maastricht) and 2005 (EU Constitution). Constitutional reform in Spain in 1992 required only three fifths of both parliamentary chambers, while the eventual reform for adapting to the EU Constitution would have required two votes of two successive legislatures after an intervening election. Similarly, in Slovakia, the normal amendment procedure requires two thirds of 
parliament, but the case launched against the ratification of the EU constitution would also have required a referendum. Under Article 7.1 of the Slovakian constitution, the process of creating a state union must be approved by referendum and, in the opinion of the claimants, the EU Constitution did precisely that: to create a state union. The same situation applies also to Latvia in relation with the Lisbon Treaty.

\section{Court decisions denying the necessity of constitutional reform: cases and strategies}

In 32 out of the 40 cases considered, Courts did not recommend constitutional reform. In order to reach such decisions, Courts pursued different paths that were not necessarily mutually exclusive and, in fact, in some cases they combined them. Rulings which did not recommend constitutional reform fell within the following four categories: either the Court used procedural instruments to avoid ruling (5.1); or they ruled with strict adhesion to the request, not exploring additional contentious issues (5.2); or they ruled on the constitutionality of the treaty together with a strong restrictive doctrinal interpretation (5.3); or they called for alternative reforms to the constitutional one (5.4). 
Table 2 Rulings and opinions on constitutionality of Treaties

\begin{tabular}{|c|c|c|c|c|}
\hline Treaty & State & Organism & Claimant & Decisions/Effects \\
\hline \multirow[t]{2}{*}{ EDC } & Germany & Constitutional Court & $\mathrm{P}$ & No definitive ruling \\
\hline & Germany & Constitutional Court & $\mathrm{H}$ & No definitive ruling \\
\hline SEA & Ireland & Supreme Court & $\mathrm{C}$ & Constitutional reform \\
\hline \multirow[t]{7}{*}{ TEU } & Denmark & Supreme Court & $\mathrm{C}$ & No constitutional reform \\
\hline & Belgium & Cour d'Arbitrage & C & No constitutional reform \\
\hline & France I & Conseil Constitutionnel & $\mathrm{H}$ & Constitutional reform \\
\hline & France II & Conseil Constitutionnel & $P$ & No constitutional reform \\
\hline & France III & Conseil Constitutionnel & $P$ & Did not admit application \\
\hline & Germany & Constitutional Court & C & No constitutional reform \\
\hline & Spain & Constitutional Court & G & Constitutional reform \\
\hline \multirow[t]{2}{*}{ Treaty of Amsterdam } & France & Conseil Constitutionnel & $\mathrm{H}+\mathrm{G}^{1}$ & Constitutional reform \\
\hline & Finland & Parliament Committee & $\mathrm{P}$ & Constitutional reform \\
\hline Treaty of Nice & Finland & Parliament Committee & $\mathrm{P}$ & No constitutional reform \\
\hline \multirow[t]{6}{*}{ EU Constitution } & France & Conseil Constitutionnel & $\mathrm{H}$ & Constitutional reform \\
\hline & Finland & Parliament Committee & $P$ & No constitutional reform \\
\hline & Spain & Constitutional Court & G & No constitutional reform \\
\hline & Slovakia & Constitutional court & $\mathrm{C}$ & No constitutional reform \\
\hline & Germany & Constitutional court & C & No action taken \\
\hline & Austria & Constitutional court & C & Did not admit application \\
\hline \multirow[t]{17}{*}{ Treaty of Lisbon } & Germany & Constitutional court & $\mathrm{C}$ & No constitutional reform \\
\hline & Czech Republic I & Constitutional Court & $\mathrm{L}$ & No constitutional reform \\
\hline & Czech Republic II & Constitutional Court & L & No constitutional reform \\
\hline & France & Conseil Constitutionnel & $\mathrm{L}$ & Constitutional reform \\
\hline & Slovenia & Constitutional Court & $\mathrm{C}$ & No constitutional reform \\
\hline & Austria I & Constitutional Court & C & Did not admit application \\
\hline & Austria II & Constitutional Court & C & Did not admit application \\
\hline & Latvia & Constitutional Court & C & No Constitutional reform \\
\hline & Poland & Constitutional Court & $\mathrm{L}$ & No Constitutional reform \\
\hline & Belgium I & Constitutional Court & C & No constitutional reform \\
\hline & Belgium II & Constitutional Court & C & No constitutional reform \\
\hline & Belgium III & Constitutional Court & C & Did not admit application \\
\hline & Hungary & Constitutional Court & C & No constitutional reform \\
\hline & UK (I) & High Court & $\mathrm{C}$ & Did not admit application \\
\hline & UK (II) & High Court & $\mathrm{C}$ & Rejected claim \\
\hline & Denmark & Supreme Court & $\mathrm{C}$ & Rejected claim \\
\hline & Finland & Parliament Committee & $\mathrm{P}$ & Constitutional reform \\
\hline \multirow[t]{4}{*}{ Accession Treaties } & Poland & Constitutional Court & $P$ & $\mathrm{~N}$ \\
\hline & Latvia & Constitutional Court & C & $\mathrm{N}$ \\
\hline & Estonia & $\ldots$ & C & $\mathrm{N}$ \\
\hline & Czech Republic & Constitutional Court & $\mathrm{P}$ & $\mathrm{N}$ \\
\hline
\end{tabular}

Source: Own elaboration. Legend: H: Head of State (President); G: Government; P: Parliament; C: Citizens. E.p.: ex post control

${ }^{1}$ The case was brought before the Court jointly by the President of the Republic and the President of the Government.

\subsection{Exploitation of procedural opportunities}


Procedures for dealing with requests for rulings on the constitutionality of treaties offer certain opportunities that courts have exploited in order to avoid explicit rulings. Courts have availed themselves of two basic instruments: timing (i.e. the option of a court to slow down or speed up proceedings) and the admissibility of demands (the acceptance or not of the appeal, without entering into the consideration of the substance of the case).

Timing played a decisive role in the 1952 German Constitutional Court case on the EDC Treaty. The Court faced two successive challenges: the opposition SPD asked the Court to prevent the Federal government from signing the treaties and to declare them unconstitutional. Judicial review applied only to formally enacted laws, and since the ratification law had not been approved the First Senate of the Federal Constitutional Court rejected the petition on procedural grounds (Loewenstein; 1955: 810). In a second challenge, the Federal president requested an advisory opinion from the Court on the constitutionality of the Treaties once the Chambers had voted on the treaty. The President finally withdrew his request. Loewenstein argues that the Court deliberatively and consistently procrastinated, since it remained completely inactive, possibly for the same political reasons that the government chose to ignore the case. Any subsequent invalidation by the Court of the treaties themselves, or of the Constitutional amendments legalizing them, would have reopened the Pandora's Box of ratification in Germany- a politically undesirable outcome which the Court was understandably not disposed to provoke. Loewenstein concludes that the Court perhaps found it was best to drag its feet and to wait for impending elections, after which the issue could be resolved by constitutional amendment. In deciding to wait, the judiciary sensibly saved face and perhaps even its own neck (Loewenstein; 1955: 837). And in fact the passage of time allowed a dramatic change in circumstances: following elections, the ruling CDU-led 
coalition obtained a large majority which permitted an amendment of the Basic Law on March, 26 1954, and removed eventual constitutional objections to the treaties. Loewenstein further argues that the Court deliberatively and consistently procrastinated until the negative vote of the French national assembly relieved it from the duty of a decision. He defines the case as one of "judicial frustration" (Loewenstein; 1955: 807).

The German and Slovak Constitutional courts exploited timing in relation to the ratification of the EU Constitution in 2005. Once the two Chambers of the German Parliament had ratified the treaty, the German President requested that the Court review it, but the latter decided to postpone the revision of the case pending the resolution of the impasse created by the French referendum. The Court never ruled on the compatibility of the EU Constitution with the Bonn Basic Law. In Slovakia, the Constitutional Court issued a preliminary decision that suspended the effectiveness of the Parliamentary approval, and declared that the President could not ratify the EU Constitution before the Court had delivered judgement. The Court resolved the case three years later, in June 2008, when it rejected the arguments of the complainants... once the EU Constitution was effectively dead.

Similarly, the French Constitutional Court used the timing of its ruling on the EU Constitution to avoid political interference with ratification. By coming to an unexpectedly quick decision, the Conseil deliberately sought to avoid interfering with the ongoing campaign inside the Socialist Party. Given that Party members were invited to vote on $1^{\text {st }}$ December, a decision published on the very eve of that vote- or after itmight have been either wrongly interpreted, or troubling in its impact. Conversely, the outcome of the referendum was not influenced because the decision had been known, analysed and commented upon one week prior to voting - the best that could be hoped for under such circumstances (Carcassone, 2005: 294). 
The second procedural instrument for avoiding an explicit ruling is admissibility. On the occasion of the ratification of the Treaty of Maastricht, the Belgian Council of State, which has an advisory capacity, considered that the Treaty (specifically, the EU citizens' right to vote) contradicted the constitutional reserve of the electoral rights for Belgian citizens, and hence it recommended that the Constitution be revised before ratification. The government immediately made it clear that it did not intend to proceed with constitutional reform and this was, according to Delpérée (1992: 648), for purely strategic reasons: while the government needed a majority of two thirds to implement constitutional reform, it only had 120 out of 212 seats in the Lower Chamber (and not the required 142). Although the Liberal Francophone party offered its seats, the government was still short of the two-thirds majority. The Cour d'Arbitrage was then challenged on the constitutionality of the right to vote. This presented a clear dilemma to the Court: if the Treaty were declared unconstitutional, it would have no direct effect at an international level, yet at a national level it would force a constitutional revision- a politically complicated process. The Court found an obvious way out of the process: it declared the application inadmissible (Claes; 2006: 97).

Similarly, in Denmark, the two cases on Maastricht had a different treatment. The Court held the ex ante case as inadmissible and accepted an ex post case, although it rejected the claims (Harcks and Olsen; 1999). In the UK cases on Lisbon, High Court Justice Collins refused to grant permission to seek a judicial review on the first, when MP Bill Cash argued that the legal consequence of the Irish negative referendum prevented the UK from proceeding with ratification. The Court held that it should be Parliament, and not the Courts, who should decide on this matter. In the second case, (which sought a judicial review of the government's refusal to hold a referendum on the 
ratification of the Treaty) High Court Justice Owen granted permission to seek a judicial review, but the High Court dismissed the claim.

The Constitutional Court of Austria has also refused to accept applications on three occasions: once in relation to the EU Constitution and twice in relation to the Lisbon Treaty. Since ex ante control is explicitly excluded in Austria, this could only happen once the Treaty was ratified. Although constitutional reform does not require very stringent majorities, questions on the validity of the Treaty when one of the ratifying member states annuls the ratification instrument spill over to the whole of the Union.

The German, Belgian and Danish cases share a common feature: the lack of a ruling avoided potentially complicated political processes of constitutional reform. Before 1954 in Germany, despite a relatively easy constitutional amendment procedure, the parties supporting the government did not have the majority required for constitutional reform (majority of two thirds in both chambers). Similarly, in Belgium and Denmark, an ex post challenge coincided with procedures for constitutional reform demanding the involvement of veto points (i.e. the dissolution of the Parliament and the approval of the reform by a two-thirds majority (Belgium) and, additionally, a referendum (Denmark). This made a possible decision of unconstitutionality highly costly in political terms.

\subsection{Strict adhesion to the request}

In a number of cases, courts have clearly restricted themselves to examining the exact and precise object of the demand, without further consideration of the Treaty at large. Some Courts strictly follow a limited question: in Spain, governments twice 
asked (in relation to the Maastricht Treaty and the EU Constitution) very precise and circumscribed questions that prima facie fended off any temptation the Court might have had to proceed any further. In some other cases, Courts have chosen to bypass a broader question in order to fence themselves off from the disputes between political parties (such as those in France over Maastricht and EU Constitution and those in the Czech Republic over the Lisbon Treaty). In relation to France and the EU Constitution, Carcassone has noted synergies between the claimant (i.e. the President) and the Court: in requesting that the Conseil scrutinise the compatibility of the two texts, Chirac left the Conseil free to determine its own approach to the question. Thanks to this astute move by the President, the judges were able to select only those issues they thought necessary to underline, something which probably spared many pointless discussions (Carcassone; 2005: 293).

The Czech Constitutional Court also showed strict adherence to the request in the first case on Lisbon. Here, the Senate asked the Constitutional Court whether the fundamental changes contained in the Lisbon Treaty were consistent with the general characteristics of the Czech Republic as a "sovereign, unitary and democratic state governed by the rule of law" and whether the ratification of the treaty would not change the "essential requirements of a democratic state governed by the rule of law", thus contradicting article 9.2 of the Czech Constitution. The President's oral intervention in the proceedings asked the Court to examine the Treaty in its entirety in relation with the Czech Constitution. The Court, however, ruled out a review of the whole text and concentrated only on the constitutionality of the six specific provisions of the Treaty of Lisbon that the Senate requested.

\subsection{No constitutional recommendation issued, but a doctrinal warning}


An attractive alternative to demanding constitutional reform is the use of legal reasoning to identify clear limits and conditions which may not be breached in the future. Thus Courts do not completely renounce their own role as masters and controllers of the process, but select a "warning" strategy. Interpretative rulings transfer the implementation problem to the future.

The German ruling on Maastricht represents the paradigm of this position. The Court identified the limits to the transfer of sovereignty to the EU and established that in future it would be prepared to control and fix these limits. Most commentaries on this verdict have rightly emphasized the ideological elements that informed it. Just as important, however, is the context surrounding the sentence: with the plaintiff demanding a preventative injunction, suspension would have been a powerful psychological blow, since the Danish and British ratifications were still pending. However, the Court rejected the injunction on the implicit understanding that there would be a speedy resolution of the case. Notwithstanding, this expectation was frustrated and the Court took 10 months to resolve the case. Again in the case of the Lisbon Treaty, the Court established the limits to European integration, the conditions for the exercise of joint competence under the principle of conferral, and the right of the Federal Constitutional Court to review the constitutionality of EC and EU law, and it did so using very assertive wording.

Similarly, the Czech Constitutional Court also issued an embedded warning in relation to the Lisbon Treaty, although it was much more contained. While it ruled unanimously that the specific objections of the Senate against the constitutionality of the Treaty were ill-founded, the Court made it clear that this decision did not rule out its possible unconstitutionality in a total sense. In any case, the ruling avoided a 
constitutional amendment which would be very difficult to achieve, given the threefifths requirement and the composition of both chambers (with the first chamber evenly split between government and opposition). The second ruling confirmed the essential aspects of the first, and explicitly criticized the President for his questioning of the notion of "shared sovereignty". To do so, the Court quoted a memorandum of the Czech government at the time when Klaus himself was Prime Minister, implicitly defending the notion of "shared" sovereignty. However, the Court warned that it could function as an ultimate arbiter, and might review whether any act by Union bodies exceeded the powers transferred by the Czech Republic to the European Union.

\subsection{Seeking alternatives to constitutional reform: imposing legislative changes}

Only one case, the ruling of the German Constitutional Court on the Lisbon Treaty, comes into this category. During the hearings on the case, in February 2009, several judges were reported to have expressed very sceptical views as to whether the Treaty ensured more democracy for EU citizens. They also expressed reservations over the number of powers to be transferred to the EU. Although the Court ruled that the Treaty was constitutional, it recommended changes to the accompanying legislation in order to improve the role of both houses of Parliament. In particular, the Court pointed to the so-called passerelle clause, which allows moving from unanimity to a qualified majority. The accompanying legislation that the German government had proposed offered the German parliament an opportunity to express an opinion. Moving a step further, the Court sentence implicitly provided the grounds for voting on passerelle decisions. Thus, the Court called for a revision of the so-called Extending Act (i.e. Act 
Extending and Strengthening the rights of the Bundestag and the Bundesrat in European Union matters).

\section{Court decisions requesting Constitutional revision}

Given the background of disputes and the general difficulty of coordination between orders, one might expect to see a large number of cases in which courts demanded a preliminary reform of the constitution (which inter alia serves the possible purpose of asserting their authority). Surprisingly, constitutional reform as a direct and immediate result of the ruling of Courts has occurred in only a very few cases: strictly speaking, in seven. The ruling on SEA in Ireland in 1986 was the first, and six other decisions happened later: in France in 1992, 2004 and 2008, when the Court adjudicated on the Treaty of Maastricht, the EU Constitution and the treaty of Lisbon respectively; in Spain in 1992, on the Maastricht Treaty, and in Finland in 1996 on the Amsterdam Treaty and in 2009 on the Treaty of Lisbon. An immediate conclusion is that cases are concentrated in very few states (i.e. four).

Ireland started the series following the Supreme Court decision of 9 April 1987 which found Title III of the SEA (concerning foreign policy) to be in contravention of the Irish Constitution. Constitutional reform would thus be required if the Irish government was to ratify the SEA. The dominant interpretation of the Crotty judgement was (and remains) that any further change in the EU constitutional order, with implications for Irish sovereignty, would have to be legitimated by referendum rather than by parliamentary statute (O’Brennan; 2008).

In all other cases, the effects of the court ruling limited themselves purely to the treaty under examination. In 1992, the French Constitutional Court found that the 
Maastricht Treaty could not be ratified unless the Constitution was amended, and allowed for sovereignty to be ceded in the following matters: EU citizens' rights in local elections, economic and monetary union, and immigration from outside the Community (Oliver; 1994: 15). In order to do so, the Court took the bold step of breaking with the old distinction between limitation and transfer of powers. The Maastricht Treaty became the first of a series of decisions subordinating ratification to constitutional reform. In 2004, with respect to the EU Constitution, and in 2008, with respect to the Lisbon Treaty, the Court again listed the items for constitutional reform. Notwithstanding, there were no major disputes in the rulings made over the compatibility between orders.

Also on Maastricht, the Spanish Constitutional Court indicated that article 13 of the Spanish Constitution needed to be reformed so as to include EU citizens' right to vote. The constitutional amendment amounted to the simple addition of one word, and the Court did not elaborate on other issues of the Treaty, thus showing a very restrained attitude. In Finland, the Constitutional Law Committee considered that the Amsterdam Treaty clashed with the Finnish constitution, and hence recommended its adoption by means of an Exception Act. The Committee ruled that the Treaty of Nice was not incompatible with the Constitution since the changes introduced were not merely necessary and corollary to the normal evolution of the Union but were, above all, largely irrelevant to the issue of Finnish sovereignty. In the case of the EU Constitution, the Committee did not deliver a specific opinion, although its views were made known in a related judgement. In 2003, the Committee noticed that the EU constitution appeared to contain a number of elements which were most likely in conflict with the Finnish constitution. As a result, an Exception Act would be required. The same interpretation was extended to the Lisbon Treaty. 


\section{Institutional factors and Higher Court decisions}

The table 3 below summarizes the cases according to the institutional features characteristic of the design of the Higher Courts.

Table 3

\section{Higher Court decisions and institutional characteristics}

\begin{tabular}{|c|c|c|c|c|c|c|c|c|c|c|c|c|c|c|c|c|c|c|}
\hline & \multirow{3}{*}{\begin{tabular}{|l}
$\begin{array}{l}\text { Type of } \\
\text { jurisdiction }\end{array}$ \\
$\begin{array}{l}\text { Moment of } \\
\text { control }\end{array}$ \\
\end{tabular}} & \multicolumn{8}{|c|}{ Ruling N } & \multirow{3}{*}{$\begin{array}{l}\text { Total } \\
\mathbf{N}\end{array}$} & \multicolumn{6}{|c|}{ Ruling Y } & \multirow{3}{*}{$\begin{array}{l}\text { Total } \\
\text { Y }\end{array}$} & \multirow{3}{*}{$\begin{array}{l}\text { Total } \\
\text { general }\end{array}$} \\
\hline & & \multicolumn{2}{|c|}{ Constitut. } & \multirow[t]{2}{*}{\begin{tabular}{|l|} 
Total \\
Const
\end{tabular}} & \multicolumn{2}{|c|}{ Ordinary } & \multirow[t]{2}{*}{$\begin{array}{l}\text { Total } \\
\text { Ord. }\end{array}$} & \multirow{2}{*}{\begin{tabular}{|l|}
$\begin{array}{l}\text { Ad } \\
\text { hoc }\end{array}$ \\
$\mathrm{A}$ \\
\end{tabular}} & \multirow{2}{*}{\begin{tabular}{|l|} 
Total \\
Ad \\
hoc
\end{tabular}} & & \multirow[t]{2}{*}{$\mathrm{C}$} & \multirow[t]{2}{*}{$\begin{array}{l}\text { Total } \\
\text { C }\end{array}$} & \multirow{2}{*}{\begin{tabular}{|l|}
$\mathrm{O}$ \\
$\mathrm{A}$
\end{tabular}} & \multirow[t]{2}{*}{$\begin{array}{l}\text { Total } \\
\text { O }\end{array}$} & \multirow{2}{*}{\begin{tabular}{|l|}
$\begin{array}{l}\text { Ad } \\
\text { hoc }\end{array}$ \\
$\mathrm{A}$
\end{tabular}} & \multirow[t]{2}{*}{$\begin{array}{l}\text { Total } \\
\text { Ad } \\
\text { hoc }\end{array}$} & & \\
\hline & & A & $\mathrm{P}$ & & A & $\mathrm{P}$ & & & & & & & & & & & & \\
\hline \multirow[t]{5}{*}{ Claimant } & C & 6 & 9 & 15 & 2 & 3 & 5 & & & 20 & & & 1 & 1 & & & 1 & 21 \\
\hline & $\mathrm{G}$ & 1 & & 1 & & & & & & 1 & 1 & 1 & & & & & 1 & 2 \\
\hline & $\mathrm{H}$ & 3 & & 3 & & & & & & 3 & 3 & 3 & & & & & 3 & 6 \\
\hline & $\mathrm{P}$ & 4 & 3 & 7 & & & & 1 & 1 & 8 & & & & & 3 & 3 & 3 & 11 \\
\hline & \begin{tabular}{|l|} 
Total \\
general
\end{tabular} & 14 & 12 & 26 & 2 & 3 & 5 & 1 & 1 & 32 & 4 & 4 & 1 & 1 & 3 & 3 & 8 & 40 \\
\hline
\end{tabular}

Source: Own compilation

Citizens have become the most active claimants in cases against treaties; this has happened on 21 occasions, while Parliaments have demanded a ruling in 11 other cases. Out of these, three cases refer to Finland and the peculiarities of the Finnish system; only the other eight cases imply a real conflictual stance. In two other cases, Presidents have held a contentious position: Germany in relation to the EDC and the Czech Republic in relation to Lisbon. Hence, in 30 out of 40 cases, claimants, be they citizens, parliaments or heads of state, have challenged decisions of the government and parliamentary majority to ratify a given treaty. Moreover, citizens have used the procedure wherever available and, taking into account a. that not all jurisdictions are open to citizens and $b$. that the requirement for a Parliament to launch an appeal may be quite high, it seems that the thesis of politicization expressed by Stone Sweet (2000) is supported by the data. Politicization, however, happens with a twist: open jurisdictions 
have made citizens rather than legislative minorities the main trigger for the involvement of the Courts.

As far as the type of jurisdiction and the moment of control are concerned, the figures and their distribution do not show any clear pattern: 30 cases in constitutional jurisdictions (26 with a negative sentence and 4 with a positive one), 6 in ordinary jurisdiction ( 5 no and 1 yes) and 4 in special ones ( 3 yes and 1 no).

\subsection{Institutional factors in affirmative Court decisions}

All cases in which constitutional reform was an immediate and direct consequence of court rulings contain the following institutional features: procedures of constitutional reform not requiring the intervention of veto points (via either referendums or intervening elections); appeals activated by the executive (or in the case of Finland, activated by an automatic process); and adjudication taking place in specialized jurisdictions. These three features constitute a model of behaviour in the case of Higher Courts adjudicating on cases referring to the ratification of EU reform treaties.

Only the Irish case provides evidence of a positive sentence (i.e. one demanding constitutional reform) which departs from this model. The Irish case differs in three aspects: a citizen activated the demand, an ordinary jurisdiction managed the case and constitutional reform required a referendum. These three features contradict the basic model and, in fact the Irish ruling in the Crotty case in 1987 came as a great surprise for many and triggered considerable criticism. Firstly, against all expectations the Court held the claim to be admissible: the safeguarding of citizens' rights to raise constitutional issues prevailed over the government's commitment to ratify on a given date. Rather surprisingly, since the High Court had never previously issued an order 
restricting the exercise of treaty-making power by the government, an interlocutory injunction was granted (Temple Lang; 1987: 709). Even then, the decision was not unanimous: with three votes to two, the majority argued that Title III of the SEA would jeopardize the Irish policy of neutrality. Moreover, in the opinion of one of the judges, it would commit Ireland to a programme that would progressively usurp Irish independence and sovereignty (sic) (Murphy; 1988: 375). Dissenting opinions held that the consent on accession in 1972 also implied an authorization for future amendments, as long as these did not alter the essential scope and objectives of the Community. The ruling prompted strong critical reactions in the Dáil, with some deputies arguing that the Court had overstepped the line of separation of powers and had granted itself the power to review treaties not foreseen in the Constitution. More radical opinions viewed the sentence as an intromission of the judiciary into a domain reserved for the legislative and the executive organs (Murphy; 1988: 376-379). In summary, the Crotty case falls outside the model, and two institutional features may explain this variance: an ordinary jurisdiction open to citizens' appeal.

Still, the Irish case shares a common institutional feature with all the other cases in which the Court demanded a constitutional reform: it is an ex ante or preliminary form of control. In other words, all cases of constitutional reform following a Court ruling on EU reform treaties occurred during the preliminary controls of constitutionality. Obviously, a ruling requiring an a posteriori revision of the constitution after the ratification of an EU reform treaty could have devastating effects. If the treaty is in contravention of the Constitution, the court either has to suspend its effects or, quite simply annul it. In either case, these effects could automatically spread to the entire Union and, hypothetically, this could eventually lead to a situation in which 
a Court could annul a Treaty for the whole of the Union. So far, no Court has tested this possibility.

Table 4

Court decisions and requirements for constitutional reform

\begin{tabular}{|c|c|c|c|}
\hline $\begin{array}{l}\text { Veto } \\
\text { Points }\end{array}$ & $\begin{array}{l}\text { Requirements for } \\
\text { constitutional } \\
\text { reform }\end{array}$ & $\begin{array}{l}\text { Cases of referrals to the } \\
\text { Constitutional/Supreme /Special Court }\end{array}$ & $\begin{array}{l}\text { Constitutional reform as result of court } \\
\text { rulings on treaty amendments }\end{array}$ \\
\hline \multirow[t]{4}{*}{ No } & Simple majority & UK (Lisbon (2) & |-------- \\
\hline & $\begin{array}{l}\text { Reinforced } \\
\text { majorities } \\
2 / 3\end{array}$ & $\begin{array}{l}\text { Austria (EU Const.; Lisbon (2) } \\
\text { Germany (EDC (2) Maastricht" Const/Lisbon) } \\
\text { Estonia (Accession) } \\
\text { Finland (Amst/Nice/EU/Lisbon) } \\
\text { Hungary (Lisbon) } \\
\text { Poland (Accession, Lisbon) } \\
\text { Slovenia (Lisbon) }\end{array}$ & Amsterdam, Lisbon \\
\hline & $3 / 5$ & $\begin{array}{l}\text { Spain (I) (Maastricht) } \\
\text { Czech Republic (Accession, Lisbon) (2) }\end{array}$ & Maastricht \\
\hline & $\begin{array}{l}\text { Majority in both } \\
\text { Chambers plus } \\
\text { Congress }\end{array}$ & $\begin{array}{l}\text { France (I) Maastricht (3), Amsterdam, EU } \\
\text { constitution, Lisbon }\end{array}$ & $\begin{array}{l}\text { Maastricht, Amsterdam, EU Constitution; } \\
\text { Lisbon }\end{array}$ \\
\hline \multirow[t]{3}{*}{ Yes } & $\begin{array}{l}\text { Majority in (both) } \\
\text { chamber(s) plus } \\
\text { Referendum }\end{array}$ & $\begin{array}{l}\text { Ireland (SEA) } \\
\text { Latvia (Accession, Lisbon) } \\
\text { Slovakia (EU Constitution) }\end{array}$ & SEA \\
\hline & $\begin{array}{l}\text { Reinforce majority in } \\
\text { two successive } \\
\text { legislatives (i.e. after } \\
\text { election) } 2 / 3\end{array}$ & Belgium (Maastricht, Lisbon (3) & ------ \\
\hline & $\begin{array}{l}\text { Majority in two } \\
\text { successive } \\
\text { legislatives plus } \\
\text { referendum } \\
\text { Simple majority } \\
\text { Reinforced } 3 / 5 \\
\text { majority }\end{array}$ & $\begin{array}{l}\text { Denmark (Maastricht, Lisbon) } \\
\text { Spain (EU Const.) }\end{array}$ & ----- \\
\hline
\end{tabular}

Source: Own compilation.

* The constitutional reform in Germany happened before the ruling of the $\mathrm{CC}$ and, hence, is not a direct consequence of this.

In summary, verdicts declaring an EU reform treaty to be against the constitution are, in all cases, ex ante controls. When the constitutional amendment procedure requires the intervention of a veto player, or a referendum and/or intervening elections, 
courts have held that an EU reform treaty does not require constitutional reform except in one case: the Crotty case in Ireland. This case represented something of an unexpected oddity. The existence of an ordinary jurisdiction and the action of citizens as triggers of the demand are the two diverging institutional features vis-à-vis the other cases in which courts demanded a constitutional reform.

Table 5

Decisions, claimants and veto players in constitutional reform

\begin{tabular}{|c|c|c|c|c|}
\hline $\begin{array}{l}\text { Veto player in constitutional } \\
\text { reform }\end{array}$ & Claimant & $\begin{array}{r}\text { Rulings } \\
\text { N }\end{array}$ & $\mathbf{Y}$ & Total \\
\hline \multirow[t]{4}{*}{$\mathbf{N}$} & C & 10 & & 10 \\
\hline & G & & 1 & 1 \\
\hline & $\mathbf{H}$ & 3 & 3 & 6 \\
\hline & $\mathbf{P}$ & 8 & 3 & 11 \\
\hline \multicolumn{2}{|l|}{ Total N } & 21 & 7 & 28 \\
\hline \multirow[t]{2}{*}{$\mathbf{Y}$} & C & 10 & 1 & 11 \\
\hline & G & 1 & & 1 \\
\hline \multicolumn{2}{|l|}{ Total Y } & 11 & 1 & 12 \\
\hline \multicolumn{2}{|l|}{ Total general } & 32 & 8 & 40 \\
\hline
\end{tabular}

\section{Conclusions}

Given certain institutional contexts, Courts cannot be totally aloof from the consequences of their rulings, and more specifically from what these rulings require in order to be implemented. In relation to rulings on the ratification of EU reform treaties, evidence indicates that Courts have decided that Treaties are against the constitution in very few cases. Strictly speaking, this has only happened in three member states: in France (three times- in 1992, 2004 and 2008), in Spain (1992) and in Ireland (1986), plus the two cases from Finland. This suggests that Courts seem to be aware of the eventual consequences of a declaration of unconstitutionality, and what is required for such a declaration to be implemented. Courts do not seem particularly oriented towards constitutional reform in relation to treaties. 
More precisely, when veto players intervene either through referendums and/or two successive votes by two different parliaments, evidence suggest that Court rulings have not called for constitutional reform. Thus, there is a relation between rulings and the stringency of the constitutional revision procedures. Courts seem to seek an accommodation between legal orders during the ratification of EU treaties, because they seem to be consistently aware of the institutional context of their decisions (i.e. the rigidity of constitutional reform rules) which very clearly set the "costs of implementation".

This is merely a partial finding in relation to the disputes on EU law. Higher Courts may decline to fight in relation to treaties during periods of ratification, but this does not mean that they do not attempt to rule against EU law. Such efforts can be channelled, for instance, through mechanisms such as strong interpretative verdicts or parallel domestic reforms (see section 5.1). This kind of behaviour fits neatly with the indirect and prospective impact of the judicialization hypothesis: the Court signals how similar disputes may be resolved in the future, and hence future rulings affect lawmaking activity (Stone Sweet, 2000: 201), transferring the implementation cost to the future. This also grants a margin of freedom to the Court itself, since interpretation may be modulated, changed or even reversed at a later stage (as, for instance, the Spanish Constitutional Court has done in relation to pre-judicial questions). Alternatively, Courts may choose to pursue their battle when the institutional environment is such that a negative ruling has a lower implementation cost (for instance, in those environments related to secondary legislation such as regulations, directives or framework decisions). In either case, the institutional environment framing Court decisions and raising specific implementation costs should be taken into account for a proper theory of constitutional judicial politics. 


\section{References}

Brouard, S. (2009) 'The politics of constitutional veto in France: Constitutional council, legislative majority and electoral competition', West European Politics 32(2): 384-403.

Carcassonne, Guy (2004) France. Conseil Constitutionnel on the European Constitutional Treaty. Decision of 19 November 2004, 2004-505 DC.1 European Constitutional Law Review, 1: 293-301, 2005

Carrubba, Clifford (2000) The politics of supranational legal integration: national governments, the European Court of Justice and development of EU law, Presented at the Midwest Political Science Association

Carrubba, Clifford James (2009) A model of endogenous development of judicial institutions in federal and international systems The Journal of Politics Vo. 71 No. 1 pp. 55-69

Clinton, Robert L. 1994. "Game Theory, Legal History, and the Origins of Judicial Review: A Revisionist Analysis of Marbury v. Madison" American Journal of Political Science 38 (2):285-302

Delpérée, Francis (1992) La Belgique et l'Europe, Revue française de droit constitutionnel, 1992, p. 643 ss

Epstein, L.; and J. Knight. 2000. "Toward a Strategic Revolution in Judicial Politics: A look back, a look ahead." Political Research Quarterly 53 (3):625-61.

Garrett, Geoffrey, R. Daniel Kelemen, and Heiner Schulz. 1998. "The European Court of Justice, National Governments, and Legal Integration in the European Union." International Organization 52 (1):149-76

Golub, J. (1996) 'The politics of judicial discretion: Rethinking the interaction between national courts and the European Court of Justice', West European Politics 19(2): 360-361

Harck, Sten and Henrik Palmer Olsen (1999) Decision Concerning the Maastricht Treaty. 1998 Ugeskrift for Retsvaesen, H 800 The American Journal of International Law, Vol. 93, No. 1, pp. 209-214

Hönnige, C. (2009) 'The electoral connection: How the pivotal judge affects oppositional success at European constitutional courts', West European Politics 35(2): 963-984.

Hönnige, C. (2011) beyond judicialization: why we need more comparative research about constitutional courts European Political Science: 10 346-358

Loewenstein, Karl (1955) The Bonn Constitution and the European Defence Community Treaties. A study in judicial frustration The Yale Law Journal vol. 64 pp. 805-839

Maduro, Miguel Poiares (2000) Europe and the Constitution: What if this is as good as it gets? Constitutionalism Web-Papers, http://www.qub.ac.uk/ies ConWeb No. 5/2000

Murphy, Finbarr (1988) El caso Crotty y el referéndum de Irlanda Revista de instituciones europeas, Vol. 15, № 2, pp. 365-382

O'Brennan, John (2008) Ireland and the Lisbon Treaty: quo vadis? CPES Policy Brief no. 176 http://www.ceps.eu http://shop.ceps.eu/BookDetail.php?item id=1741 Accessed 29 December 2008

Oliver, Peter (1994) The French constitution and the Treaty of Maastricht International and Comparative Law Quarterly vol. 43 pp. 1-25

Ras, Bjorn Erik and Roger D. Congleton; 2006: Amendment procedures and constitutional stability, in Congleton, Roger D. and Birgitta Swedenborg (eds.) Democratic constitutional design and public policy: analysis and evidence, Cambridge, MA: MIT Press pp. 319-342 
Rosenberg, Gerald N. (1991) The Hollow hope: can courts bring about social change Chicago University Press

Santoni, M. and Zucchini, F. (2004) 'Does policy stability increase the constitutional court's independence? The case of Italy during the first republic (1956-1992)', Public Choice 120(3-4): 401-439

Stone Sweet, A. (2000) Governing with Judges. Constitutional Politics in Europe, Oxford: Oxford UP.

Temple Lang, John (1987) The Irish Court case which delayed the Single European Act: Crotty v. An Taoiseach and others, 24, CML Rev. (1987), 709

Vanberg, Georg (2001) Legislative-judicial relations: a game-theoretic approach to constitutional review American Journal of Political Science Vol. 45 No. 2 pp. 346-361

De Witte, Bruno (2004) Treaty revision in the European Union: constitutional change through international law Netherlands Yearbook of International Law (2004), 35: 51-84 


\section{Table of cases}

\begin{tabular}{|c|c|c|}
\hline UK & Lisbon I & $\begin{array}{l}\text { Case [2008] EWHC } 1409 \text { (Admin) (C0/1915/2008), Wheeler v Prime Minister, } \\
\text { judgement of } 25 \text { June } 2008\end{array}$ \\
\hline & Lisbon II & Judicial Review CO/5743/2008 \\
\hline \multirow[t]{4}{*}{ Austria } & EU Const & Case G 62/05 Constitutional Treaty, order of 18 June 2005 \\
\hline & Lisbon I & Case SV 2/08-3 et al. Treaty of Lisbon I, order of 30 September 2008 \\
\hline & Lisbon II & Case G 149-152/08-5, Treaty of Lisbon II judgement of 11 March 2009. \\
\hline & Lisbon III & Case SV 1/10-9 Treaty of Lisbon III, order of 12 June 2010 \\
\hline Estonia & Accession & $\begin{array}{l}\text { Decision No 3-4-1-11-03 of 24 September } 2003 \text { Vilu and Estonian Voters } \\
\text { Union and Decision No 3-4-1-12-03 of } 29 \text { September } 2003 \text { Kulbok }\end{array}$ \\
\hline \multirow[t]{4}{*}{ Finland } & Amsterdam & \\
\hline & Nice & \\
\hline & EU Const & \\
\hline & Lisbon & \\
\hline Hungary & Lisbon & Case 143/2010 (VII. 14) Treaty of Lisbon, judgement of 12 July 2010 \\
\hline \multirow[t]{2}{*}{ Poland } & Accession & Case K 18/04 Accession Treaty of 11 May 2005 \\
\hline & Lisbon & Case K 32/09 Treaty of Lisbon, judgement of 23 November 2010 \\
\hline Slovenia & Lisbon & Case UI-49/08 Treaty of Lisbon, judgement of 17 October 2008 \\
\hline \multirow[t]{2}{*}{ Spain } & Maastricht & Case 001/1992 Maastricht Treaty, declaration of 01 July 1992 \\
\hline & EU Const & Case 1/2004 Constitutional Treaty, declaration of 13 December 2004 \\
\hline \multirow[t]{3}{*}{ Czech Republic } & Accession & Case PL ÚS 1/04 Accession Treaty, judgement of 4 March 2004 \\
\hline & Lisbon I & Case PL ÚS 19/08 Treaty of Lisbon I, order of 30 September 2008 \\
\hline & Lisbon II & Case PI ÚS 29/09 Treaty of Lisbon II, judgement of 3 November 2009 \\
\hline \multirow[t]{6}{*}{ France } & Maastricht I & Case No. 92-308 DC Maastricht I, decision of 9 April 1992 \\
\hline & Maastricht II & Case 92-312 DC Maastricht II, decision of 2 September 1992 \\
\hline & Maastricht III & Case 92-313 DC Maastricht III, decision of 23 September 1992 \\
\hline & Amsterdam & Case 97-394 DC Amsterdam, decision of 31 December 1997 \\
\hline & EU Const & Case 2004-505 DC Constitutional Treaty, decision of 19 Nov. 2004 \\
\hline & Lisbon & Case 2007-560 DC Treaty of Lisbon, decision of 20 December 2007 \\
\hline Ireland & SEA & Case 1986 No.12036P, Crotty v. An Taoiseach \\
\hline \multirow[t]{2}{*}{ Latvia } & Accession & Cases $119-123 / 2003$ \\
\hline & Lisbon & Case 2008-35-01 Treaty of Lisbon, judgement of 7 April 2009 \\
\hline Slovakia & EU Const & $\begin{array}{l}\text { Case II. U.S. 171/05-175 Constitutional Treaty, judgement of } 27 \text { February } \\
2008\end{array}$ \\
\hline \multirow[t]{4}{*}{ Belgium } & Maastricht & $\begin{array}{l}\text { State Council, Recommendation } 482 / 1-91 / 92 \text { (S.E.) on the Project of law } \\
\text { authorising the ratification of the Treaty on the European Union, of } 17 \\
\text { Protocols and of a Final Act with } 33 \text { Declarations, done in Maastricht the } 7^{\text {th }} \\
\text { February } 1992 \text {. }\end{array}$ \\
\hline & Lisbon I & Constitutional Court, Case 58/2009, judgement of 19 March 2009 \\
\hline & Lisbon II & Constitutional Court, Case 125/2009, judgement of 16 July 2009 \\
\hline & Lisbon III & Constitutional Court, Case 156/2009, judgement of 13 October 2009 \\
\hline \multirow[t]{2}{*}{ Denmark } & Maastricht & Case I 361/1997 Carlsen v. Rasmussen, judgement of 6 April 1998 \\
\hline & Lisbon & Not yet reported \\
\hline \multirow[t]{5}{*}{ Germany } & EDC Treaty I & Case 1 BvG 396 \\
\hline & EDC Treaty II & No decision \\
\hline & Maastricht & Case 2 BvR 2134 et al. Treaty of Maastricht, judgement of 12 October 1993 \\
\hline & EU Const & No decision \\
\hline & Lisbon & Case 2 BvE 2/08 et alt. Treaty of Lisbon, judgement of 30 June 2009. \\
\hline
\end{tabular}

